\title{
INTEGRATED BEACH MANAGEMENT AT IGEA MARINA, ITALY: RESULTS OF TEN-YEARS MONITORING
}

\author{
M. Preti ${ }^{1}$, B. Zanuttigh ${ }^{2}$, N. De Nigris ${ }^{1}$, L. Martinelli², M. Aguzzi ${ }^{1}$, R. Archetti ${ }^{2}$ and A. \\ Lamberti $^{2}$
}

\begin{abstract}
This contribution analyses the hydro-morphological effects induced by low crested structures confined by lateral groynes at Igea Marina beach, Northern Adriatic Sea, Italy The site has been monitored since the works started for these last ten years. Results from bathymetric surveys, sediment samplings, video monitoring and numerical modelling are presented and discussed.
\end{abstract}

Keywords: low crested structures; integrated coastal zone management; sustainability; monitoring; modelling

\section{INTRODUCTION}

Major threats for large stretches of European coasts are erosion and flooding, which are mainly caused by: loss of river sediment load; subsidence; inappropriate interception of long-shore transport; dune decay; effects of climate change (Nicholls and de la Vega-Leinert, 2008; Nicholls and Klein, 2005).

The Mediterranean areas will be among those most stricken by climate change and a great deal of damages is to be expected given also the increasing anthropogenic pressure along the coasts (318 to 584 cities from 1950 to 2005, about 70 million of people in year 2000 forecasted to be up to 90 million by 2025 -Plan Bleu Report, 2005).

This picture points out the need of a strategic, sustainable and integrated management of the resource "sediment.

The littoral of the Emilia-Romagna Region, in the Adriatic Sea, is an example of coastal zone with a series of erosive problems, accentuated by its long-term strong urbanization. Tourism in the area has a strong economic impact: in the period May-September 2006, 41 million daily presences caused a gross income of 9.8 billion $€$ (Figure 1.). A decennial plan for this area was recently published addressing the issue of integrated coastal zone management (Preti et al., 2009).

The Littoral of the Emilia-Romagna Region stretches for $130 \mathrm{~km}$, of which $40 \mathrm{~km}$ are protected by coastal parallel detached breakwaters. However, the beaches protected by breakwater are in erosion due to subsidence and low supply of river sediment.

The coastal breakwaters have guarantied a good protection of the beach against sea erosion, but at the same time the structures have caused a high environmental and landscape impact, in same cases worsening of the water quality and a high sedimentation of silts and clay.

Since mid-'80s, local authorities have studied new solutions to defend the shore and to reduce environmental impact of breakwaters.

In order to limit the impact of the detached breakwaters in 2001, the Emilia-Romagna Region has committed to ARPA (Agenzia Regionale Prevenzione e Ambiente, Environmental and Prevention Regional Agency), a study aimed to propose an alternative scheme for the coastal defence.

The selected study site is a stretch of $800 \mathrm{~m}$ of beach in Igea Marina, Rimini, Italy (Figure 2.). The selected protection scheme was made by a Low Crested Structure (hereinafter LCS), boundary groins and a nourishment. The experimental design was carried out in 2003. The detailed description of the site and of the structures is presented in next chapter.

Aims of the experimental project were:

- $\quad$ to defend beach and settlements from marine ingression;

- $\quad$ to improve the seabed and water quality;

- $\quad$ to restore the beach;

- to reduce environmental and landscape impact of breakwaters.

The work intervention was monitored in the following phases:

\footnotetext{
${ }^{1}$ ARPA Direzione Tecnica. Largo Caduti del Lavoro, 6. 40122 Bologna. Italy. mpreti@arpa.emr.it

${ }^{2}$ University of Bologna, DICAM, Viale Risorgimento,2. 40136 Bologna. Italy. barbara.zanuttigh@unibo.it
} 
- 2000 - 2003. Pre construction monitoring by ARPA (Topography, grain size analysis, water quality sampling, Aereo photogrammetric surveys);

- 2003 - 2009. Post construction monitoring by ARPA (Topography, grain size analysis, water quality sampling, Aereo photogrammetric surveys);

-2005 - 2008. Monitoring and study of the effects of the LCS on the beach by DISTART (now DICAM), University of Bologna (Videomonitoring, wave currents measurement, numerical modeling)

The paper presents the results of the articulated monitoring activities, the effectiveness of the intervention and the applicability of this breakwater scheme to other sites.

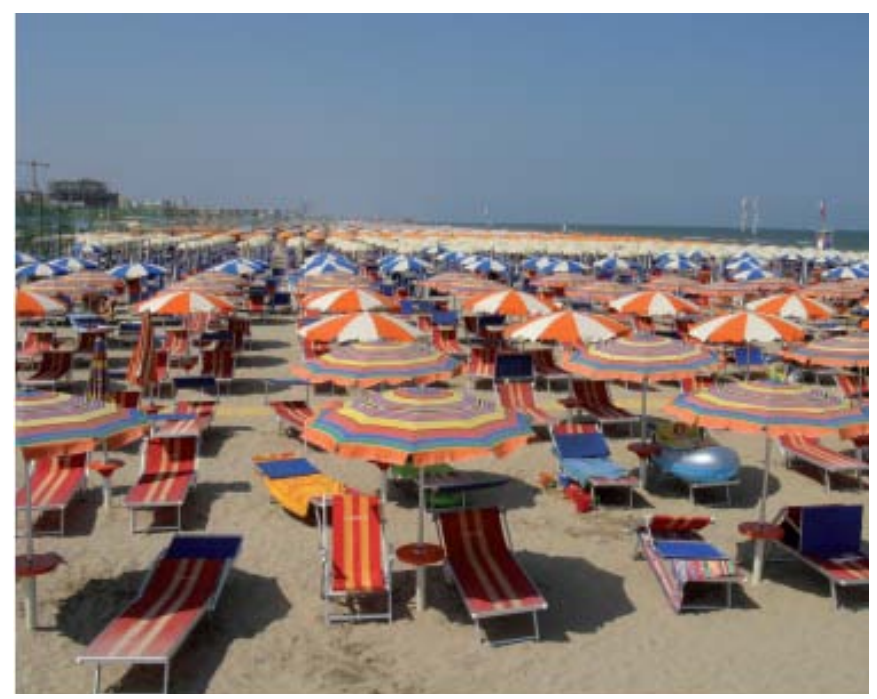

Figure 1. Example of the beach exploitation along the Emilia-Romagna Coast

\section{DESCRIPTION OF THE SITE}

\section{The intervention}

Igea Marina is located $15 \mathrm{~km}$ North of Rimini (Figure 2.), the area between the outlets of the Uso river Northwards and the outlet of the artificial Pedrera channel Southwards. The site is located at the centre of a $20 \mathrm{~km}$ long continuous array of detached emerged barriers (from Cesenatico to Rimini) (Figure 3.).

These barriers have been such an hindrance to recreational activities, that in 2003 the EmiliaRomagna Region started an experimental program aiming at improving the sea bed and the water quality (Preti, 2005).
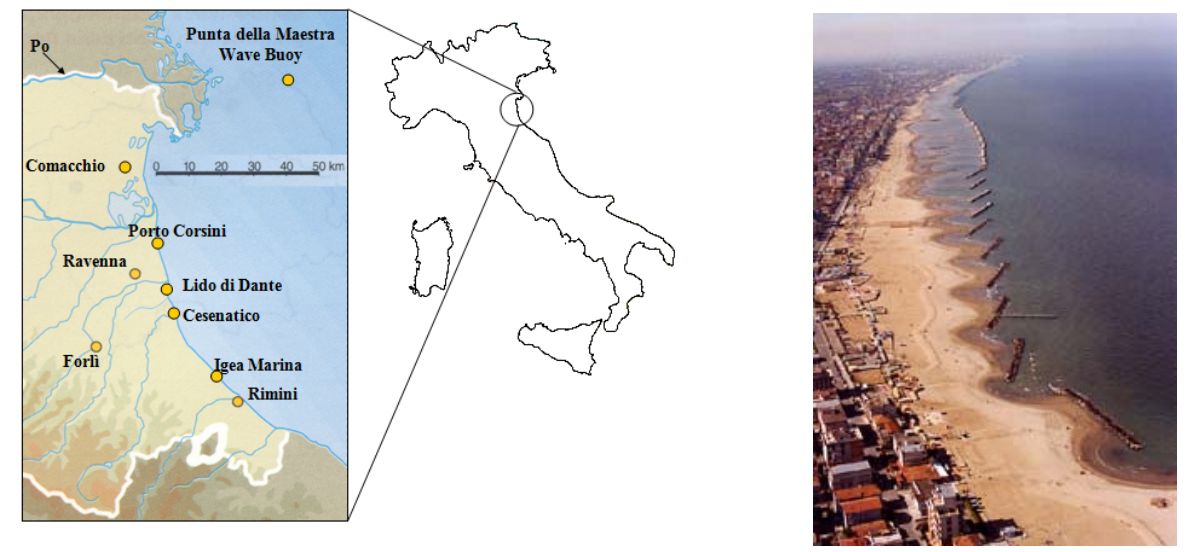

Figure 2. Location of Igea Marina along the Emilia-Romagna littoral (Italy) left and aerial view of the protected beach near Igea Marina 

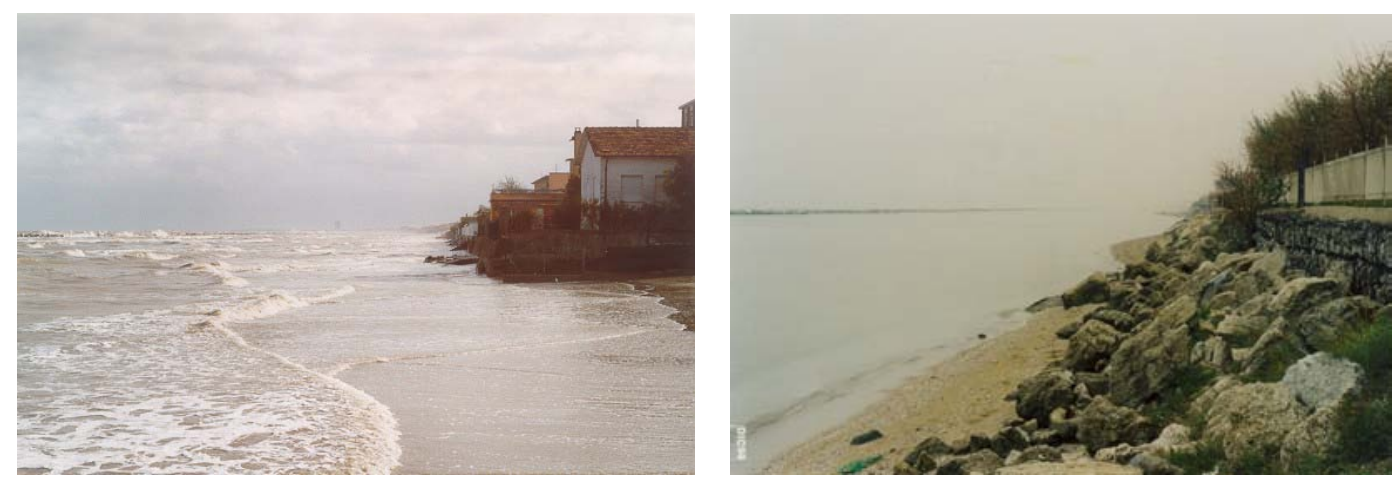

Figure 3. Igea Marina beach in 2001, before the experimental intervention

For this purpose, an $800 \mathrm{~m}$ long beach in Igea Marina was selected (Figure 2.). Before the construction project, the site suffered from many problems: the beach was narrow (Figure 3.); water depth behind the structures was very limited and did not allow bathing and recreational activity. Also scour at the barrier offshore side was pronounced.

The project was subdivided into two phases:

- the lowering of the crest of six emerged barriers to mean sea level, reaching a crest width of $18 \mathrm{~m}$, and the partial closure of the gaps in between, with an alternate depth of 0.5 and $1 \mathrm{~m}$ (Spring 2003), the nominal diameter $D_{n 50}$ of the barrier was the same as the previous emerged barrier $\left(\mathrm{D}_{\mathrm{n} 50}=1.0 \mathrm{~m}\right)$;

- the confinement of the renewed cell with two lateral groynes, which start at a $1 \mathrm{~m}$ top crest on the beach and progressively reach $-0.5 \mathrm{~m}$ at the structure roundheads (October 2003). Design plan of the scheme and design conditions are described in Preti et al., (2005).

A scheme of the new lay out is presented in Figure 4.

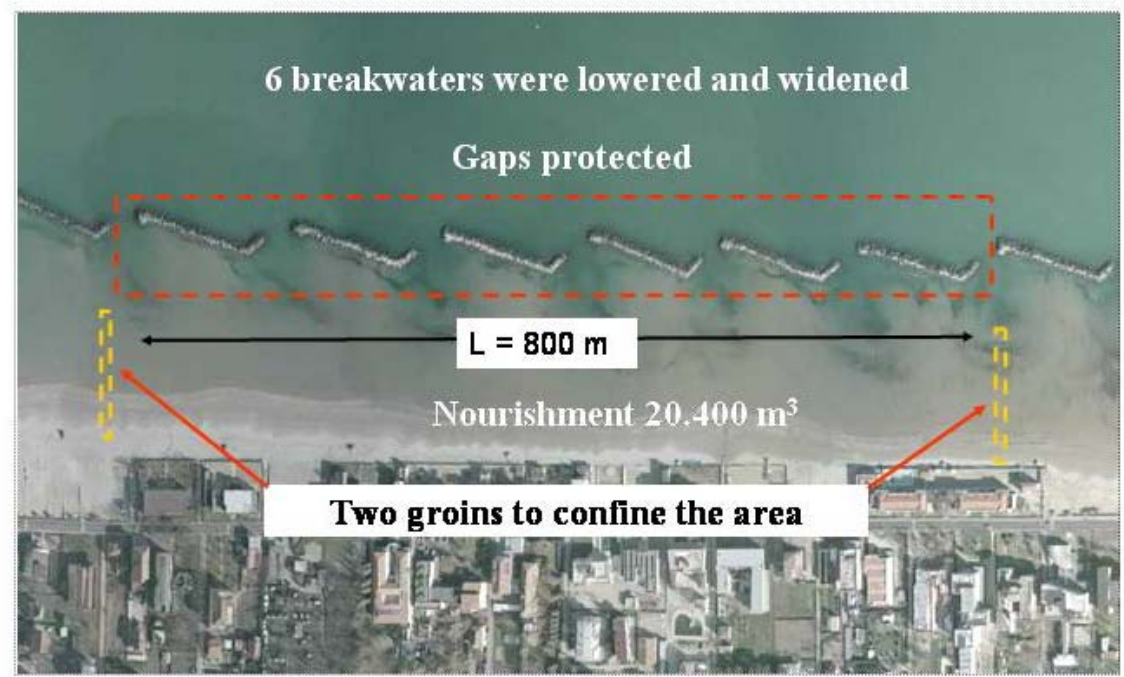

Figure 4 Lay out of experimental project carried out in Igea Marina (2003)

In December 2003, after a storm of moderate intensity -well below design conditions-, the groynes collapsed with greatest damages at the roundheads and scour depths reaching $6 \mathrm{~m}$ at the sides (Martinelli et al., 2007). Groynes were finally restored in May 2005.

In February 2007 a local small nourishment commissioned by the local City Council was performed, (approx. $8 \mathrm{~m}^{3} / \mathrm{m}$ of sand). In April-May 2007 there was a nourishment of around $65 \mathrm{~m}^{3} / \mathrm{m}$ of sand dredged from relict deposits (Preti et al., 2009). 


\section{Environmental conditions}

The Adriatic Sea along the Emilia-Romagna littoral is characterized by a maximum depth of around 50 meters. Normally, eutrophic conditions are caused by waters drained by the Po River from the highly inhabited and cultivated Po plain.

Meteorological and wave observations were carried out on the numerous gas platforms just in front of Ravenna. Visual observations from the PCB platform and (KNMI) ships were done in the period 1971-1983, whereas measurements from AGIP platforms were performed since 1992 (IDROSER, 1996). More recently, two buoys were installed: one in Ancona, (in 1999), at $50 \mathrm{~m}$ depth, and one in Punta della Maestra, (in 2002), at $34 \mathrm{~m}$ depth by the National Wave Service. The buoy in Punta della Maestra (Figure 1.) was frequently damaged due to collisions with sea vessels and ultinately removed in 2006. A new wave buoy was installed in May 2007 within BEACHMED-e project (www.beachmed.eu). The buoy was placed at about $5.5 \mathrm{~km}$ offshore Cesenatico over a $10 \mathrm{~m}$ deep bottom. The acquisition system is at the Centro Ricerche Marine Cesenatico: data are logged every 30 minutes and stored.

The tidal variation in this area is low, being the average spring tide range $\pm 0.4 \mathrm{~m}$ and the extreme yearly values around $+0.85 \mathrm{~m}$. Most intense storm events come from N, NE (known as Bora) and S SE (known as Scirocco) with similar intensity; waves may reach $3.5 \mathrm{~m}$ every year and rise up to $6 \mathrm{~m}$ every 100 years. Wind intensity is stronger from the shorter fetch sector of Bora where it frequently reaches $18 \mathrm{~m} / \mathrm{s}$ intensity. Whereas, from the longer fetch sector of Scirocco it seldom exceeds $16 \mathrm{~m} / \mathrm{s}$.

\section{MONITORING PROGRAM}

The first cross-shore profiles in the area are available since 2000. An intensive monitoring program started in December 2003, consisting of:

- $\quad$ single and multi-beam surveys, carried out once per year to check sand losses;

- multi-beam surveys to monitor scour holes at gaps due to rip currents;

- $\quad$ sediment samples, for determining grain size re-distribution;

- $\quad$ aereo photogrammetric surveys;

- $\quad$ video monitoring of the shoreline position;

- $\quad$ wave- current survey with ADCP.

Last available data were collected in summer 2009.

A synthesis of data surveys and monitoring activities is presented in Table 1.

\begin{tabular}{|c|c|}
\hline Date & Activity \\
\hline Jan. 2003 & Collection of aerial pictures \\
\hline Feb. 2003 & Topobathymetric survey (21 profiles) \\
\hline Mar. 2003 & Collection of 15 sediment samples \\
\hline May-Apr. 2003 & Nourishment with $9^{\prime} 700 \mathrm{~m}^{3}$ of sand \\
\hline Spring 2003 & Transformation of the detached barriers into low crested structures \\
\hline May and Jul. 2003 & $\begin{array}{l}\text { Collection of } 3 \text { water samples for bacteriological analysis and } 3 \\
\text { sediment samples for chemical analysis }\end{array}$ \\
\hline Oct. 2003 & Collection of aerial pictures \\
\hline Oct.-Nov. 2003 & Building of Southern and Northern groins \\
\hline 3-4 Dec. 2003 & Topobathymetric survey (21 cross-shore and 4 long-shore profiles) \\
\hline 7-8 Dec. 2003 & Storm causing damages to the groins \\
\hline Dec. 2003 & Bathymetric survey close to damaged groins \\
\hline Jan.-Feb. 2004 & Nourishment with $10^{\prime} 000 \mathrm{~m}^{3}$ of sand \\
\hline July 2004 & Collection of aerial pictures \\
\hline Sep. 2004 & $\begin{array}{l}\text { Collection of } 5 \text { water samples for bacteriological analysis and } 3 \\
\text { sediment samples for chemical analysis }\end{array}$ \\
\hline Nov. 2004 & $\begin{array}{l}\text { Topobathymetric survey (16 cross-shore and } 6 \text { long-shore profiles } \\
\text { and Multibeam survey analysing erosion at the sides of the } \\
\text { damaged groins) }\end{array}$ \\
\hline Apr. 2005 & Collection of 15 sediment samples \\
\hline May 2005 & Bathymetric survey close to groins \\
\hline May 2005 & Groin repair \\
\hline Feb.2006 & $\begin{array}{l}\text { Topobathymetric Multibeam survey analysing erosion at the sides } \\
\text { of the repaired groins }\end{array}$ \\
\hline May 2006 & Nourishment with $10^{\prime} 000 \mathrm{~m}^{3}$ of sand \\
\hline
\end{tabular}




\begin{tabular}{|l|l|}
\hline Oct. 2006 & $\begin{array}{l}\text { Geotechnical survey: 4 CPTU with 41 pore pressure dissipation } \\
\text { tests, 4 SPT and 2 continuously cored boreholes until 10 m depth }\end{array}$ \\
\hline $\begin{array}{l}\text { Oct 2006 - Feb } \\
2008\end{array}$ & Video monitoring of the shoreline position \\
\hline $\begin{array}{l}\text { Dec 2007 - Feb } \\
2008\end{array}$ & Wave- current survey with ADCP \\
\hline October 2008 & $\begin{array}{l}\text { Topobathymetric survey (16 cross-shore and 6 long-shore profiles } \\
\text { and Multibeam survey analysing erosion at the sides of the } \\
\text { damaged groins) }\end{array}$ \\
\hline July 2009 & $\begin{array}{l}\text { Topobathymetric survey (16 cross-shore and 6 long-shore profiles } \\
\text { and Multibeam survey analysing erosion at the sides of the } \\
\text { damaged groins) }\end{array}$ \\
\hline
\end{tabular}

Sediment samples were collected in 2003 and in 2005 at different depths, along 3 cross-shore profiles, 2 of which inside the protected area and the other $300 \mathrm{~m}$ Southward.

Grain size on the beach (at $+1.0,0.0$ and $-1.0 \mathrm{~m}$ of depth) is approximately the same in both surveys, whereas at the depths of -2.0 and $-4.0 \mathrm{~m}$ an increase in grain mean diameters from 2003 to 2005 can be appreciated (Figure 5.). The increase in grain size in the leeward side of the protected area is caused partially by the removal of fine materials due to a greater wave overtopping behind the low crested barriers and partially by yearly nourishments of sand dredged from a nearby harbour.

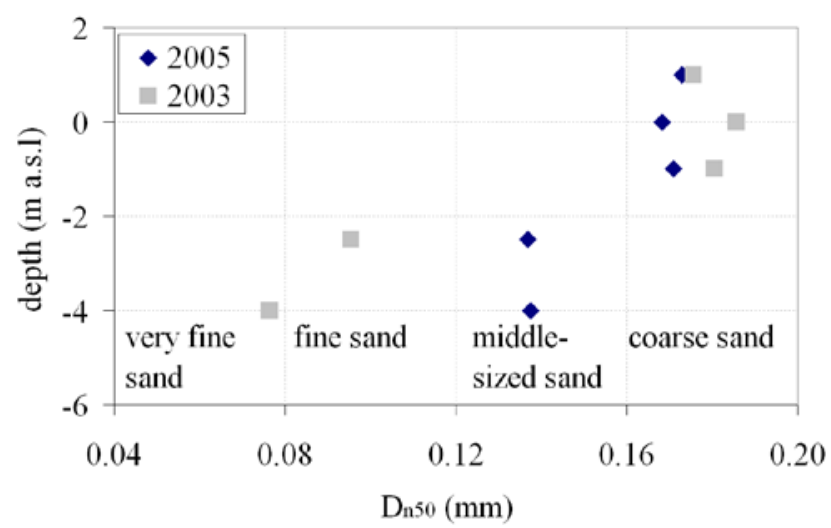

Figure 5. Grain size: comparison between 2003 and 2005 samples.

In the next Figure 6. the results of the comparison among following bathymetric surveys are presented. 

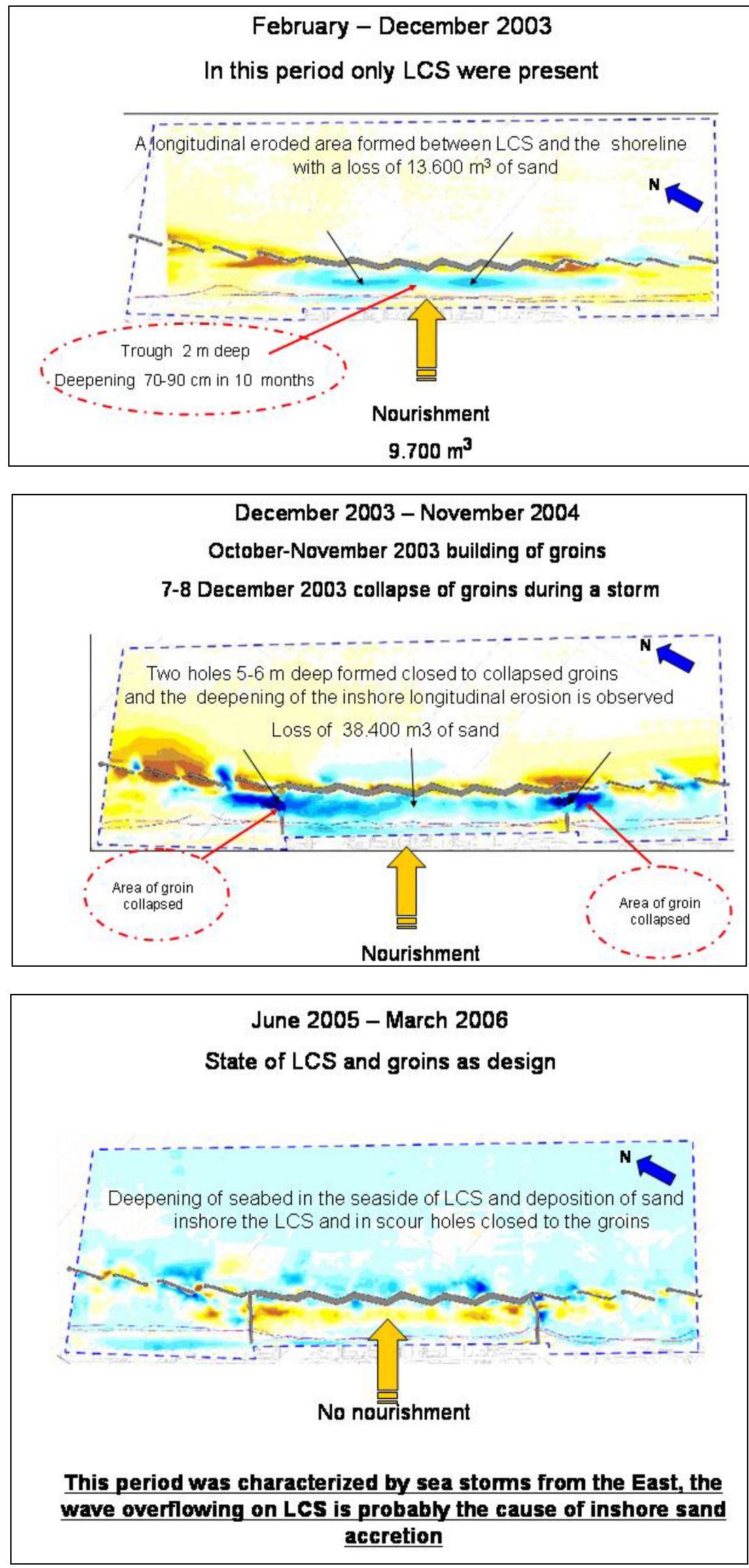

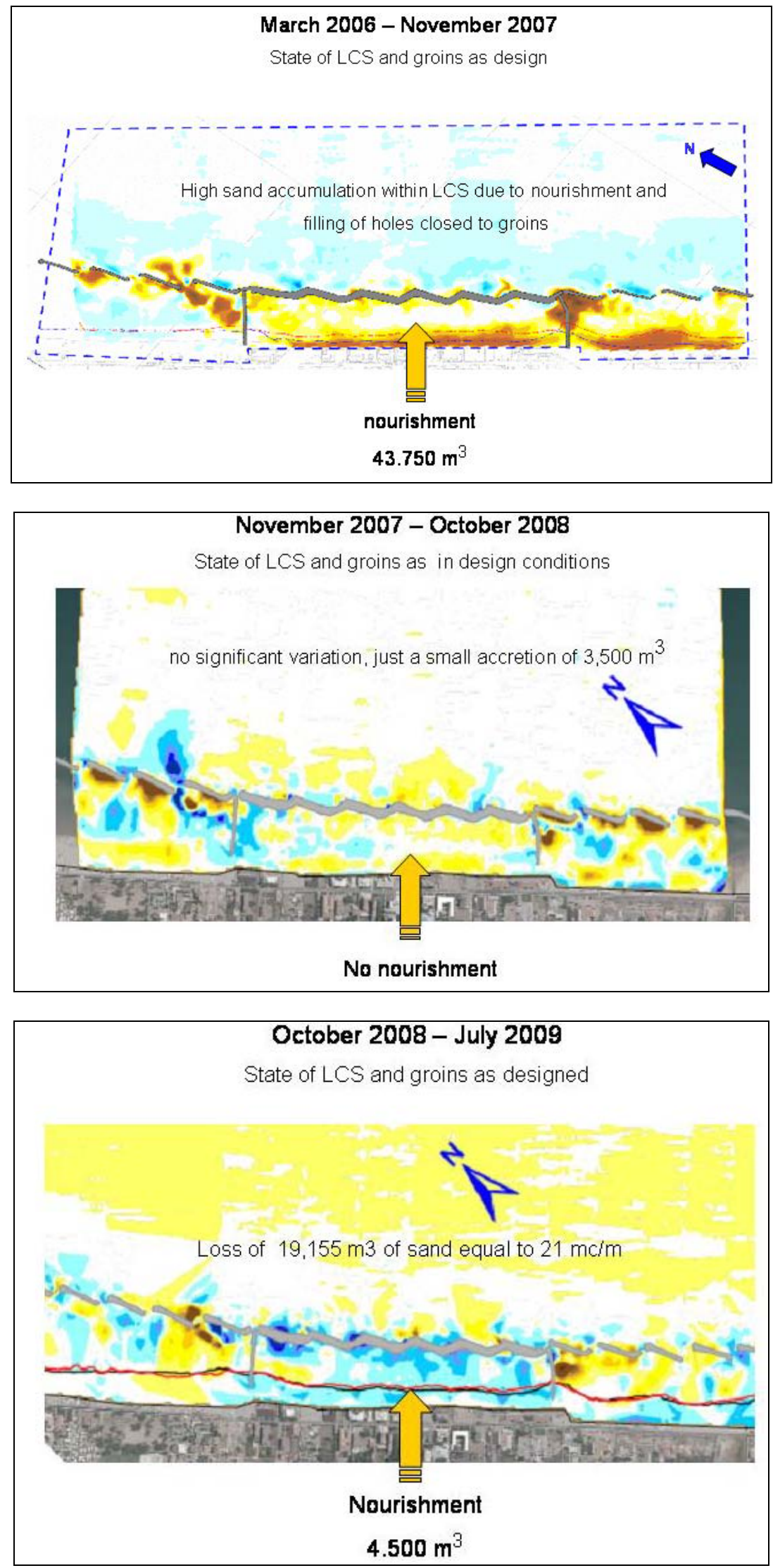

Figure 6. Results of bathymetric analysis: differences of volume sand between following surveys. 
Maps in Figure 6. show different performances depending breakwaters and groins assets and sea storms directions.

In between 2005 and 2009, just after groins rebuilding, two different performances has been observed in the experimental area: from June 2005 to October 2008 no sand loss has been detected, from October 2008 to July 2009 a relevant loss of sand has been measured (around $30 \mathrm{m3} / \mathrm{m}$ ).

The first period was dominated by sea storms from North-East; the second period was characterized by sea storms from South-East.

From December 2003 to June 2005 a relevant loss of sand was caused by the absence of groins or by their collapse.

The above considerations clearly demonstrate that, in situations similar to those studied in this experimental work, the groins play a very important role.

\section{Video monitoring and current and wave measurements}

The video station in Igea Marina has been installed in October 2006 by the DISTART University of Bologna and has been working for 2 years. The station was composed of two video systems. The first video system looks to the North and the second video system looking towards the South is composed of two 8 megapixel digital still cameras Olympus SP500UZ mounted in a single housing. The systems were set to collect snapshot and timex images (Figure 7.).

The study of various shoreline features and processes is facilitated by transforming the images into real world coordinates. The reference system of the survey has the origin at the video camera location and is rotated $36^{\circ}$ in order to have the orientation of the $\mathrm{x}$-axis normal to the shoreline, with the positive $\mathrm{x}$ axis pointing in seaward direction. The y-axis is directed perpendicular to the x-axis, such that the coordinate system thus obtained is positive in mathematical sense. In this reference the structures parallel to the shore are $\mathrm{y}$-oriented and the groins $\mathrm{x}$-oriented (Figure 8.).

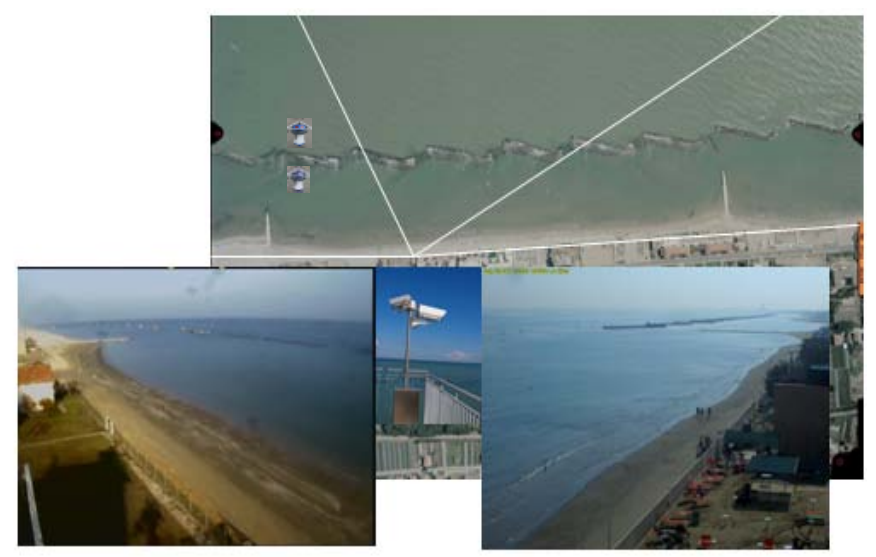

Figure 7. The video station in Igea Marina and The positions of the two ADCPs

A detailed description of the video system and of the orthorectification process is given in Archetti et al., 2009, Archetti and Zanuttigh 2010.

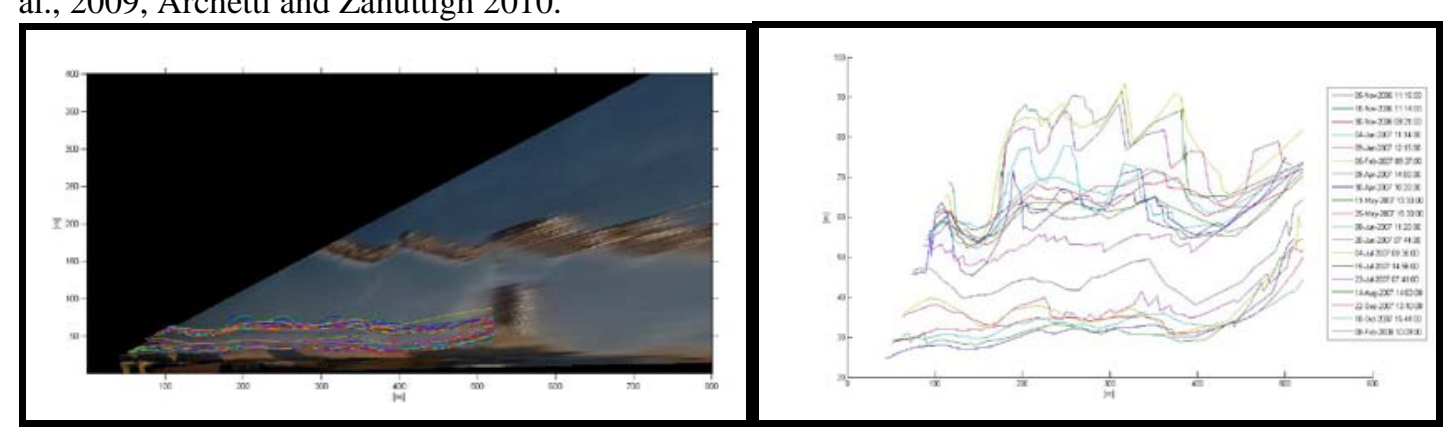

Figure 8. A total of 20 shorelines plotted on plan-view images during a 16 month period. 
In order to quantify changes in coastal features and nearshore processes, and to have at any time the information on the state of the beach (width, shoreline position), the shoreline at selected times was detected on ortorectified images (Figure 8). The shorelines keep constant during winter 2007 with same small fluctuation of the order of few meters in coincidence with storm events. The behaviour of different sections is comparable, except for section 400 which shows more evident retreat during storms. The same behaivour was observed also looking at the past data. In April, beach nourishment produced an advance in the shoreline position varying from 20 to $40 \mathrm{~m}$ in different sections of the beach. After the first nourishment assessment, the beach dimension was maintained.

During the period December 2007-March 2008 a field campaign was performed by installing two ADCPs seaward and landward the barriers to monitor wave transmission and current intensity at gaps. The seaward and the inshore ADCPs were placed on a $2.5 \mathrm{~m}$ and $2.4 \mathrm{~m}$ bottom depth respectively. The positions of the two ADCPs are shown in Figure 7.

The ADCPs hourly measured waves (significant wave height, wave peak period, average wave period, mean wave direction) and currents (average intensity and direction). ADCP measurements were used for the numerical modeling calibration.

\section{NUMERICAL MODELLING}

The purpose of this analysis is to evaluate the hydro-morpho-dynamics induced by the intervention at Igea Marina beach.

Simulations of waves, currents and sediment fluxes have been carried out using MIKE 21 Release 2007, a 2DH numerical modelling suite developed by DHI Water \& Environment \& Health. In particular, the Nearshore Spectral Wave (NSW) module was adopted for propagating waves from offshore in front of the structures, the Parabolic Mild Slope (PMS) module for simulating waves around the structures and the Hydrodynamic (HD) module for simulating currents.

The NSW model is a wind-wave model, which describes the growth, decay and transformation of wind-generated waves and swell in near shore areas. The model is a stationary, directionally decoupled parametric model and takes into account the effects of refraction and shoaling, local wind generation, energy dissipation due to bottom friction and wave breaking, wave-current interaction. The basic equations in the model are derived from the conservation equation for the spectral wave action density and are solved using an Eulerian finite difference technique. The PMS module is based on the parabolic approximation of the mild-slope equation of Kirby (1986), who assumes a predominant wave direction and neglects wave diffraction and back-scattering in the direction of wave propagation. The HD module solves the full time-dependent non-linear equations of mass and momentum balance. The solution is obtained using an implicit ADI (Alternating Direction Implicit) finite-difference secondorder accurate scheme, see e.g. Abbot et al. (1973) for details.

In order to reduce the computing time without losing the wave effects on the global littoral regime, hydrodynamic simulations have been performed using a representative wave climate, considering the typical low tide $(-0.5 \mathrm{~m})$, i.e. the worst condition for water exchange behind the barriers, and including wind effects. In the NSW and PMS module, a series of irregular directional waves with Jonswap spectra were imposed as offshore condition, in order to have a realistic estimate of radiation stresses, wave set-up and boundary conditions for the HD module. Lateral boundaries in both wave modules were assumed to be "symmetrical", in order to properly represent open-sea conditions. The wave breaking parameters were the default suggested values: $\gamma_{1}=1.0$ (controls steepness breaking), $\gamma_{2}=1.0$ (controls depth limited breaking) and $\alpha=0.8$ (controls breaking dissipation rate). For the HD module, off-shore boundary condition was null flux, whereas lateral boundary conditions were the levels derived from the radiation stresses calculated with the PMS module. Eddy viscosity was computed using the velocity based Smagorinski formulation with a constant coefficient equal to 0.8 .

The weaknesses of the numerical results are mainly related to the missing representation of wave transmission in presence of zero freeboard and emerged structures. In these simulations, an attempt to represent wave overtopping (and rip currents) also in emergent conditions is done with the placement of pairs of sources and sinks with a given overtopping discharge (method described in Zanuttigh and Lamberti, 2006), where the discharge is estimated based on the formula by Van der Meer \& Janssen (1995) for surging waves.

Wave propagation and current modelling were performed on a bathymetry (Figure 3.) based on the survey of April 2007, which was carried out immediately before the maintenance nourishment and is thus supposed to give the picture of the beach close to its equilibrium status. Spatial resolution of the computational grid is $2 \mathrm{x} 2 \mathrm{~m}$, grid extension is $3000 \mathrm{~m}$ long-shore and $900 \mathrm{~m}$ cross-shore. The structures 
(barriers and groynes) were included with the size and elevation as in the design, including the protection at gaps.

Table 2. summarises the representative wave climate extracted from the NSW module in front of the barriers, over a $4 \mathrm{~m}$ depth, together with the most relevant results obtained from the simulations. Typical current circulation for Bora and Scirocco storms is shown in Figure 4.

The barrier is efficient in the reduction of the wave height, being the average value of the transmission coefficient around 0.30. Residual wave agitation behind the barrier guarantees sufficient water recirculation even for the lowest wave height (Wave 7) and safe conditions for swimmers even in presence of the highest incident wave (Wave 2).

The most intense currents (up to $1 \mathrm{~m} / \mathrm{s}$ ) develop around the barriers and at the roundheads of the groynes. Since these currents are directed inshore there is no potential risk for swimmers, with the exception of the area between the Northern groyne and the gap of the first barrier to the North during Waves 1 and 2.

The circulation pattern along the barrier appears to be substantially independent from the long-shore currents in the surf zone and rip currents at gaps are particularly intense when the direction of wave attack differs from the perpendicular to the barrier axis, i.e. from the prevailing metoemarine condition (Scirocco) on which the barrier design is based.

\begin{tabular}{|c|c|c|c|c|c|c|c|c|}
\hline Wave \# & MWD & $\mathrm{H}_{\mathrm{si}} \mathrm{m}$ & $\mathrm{T}_{\mathrm{m}} \mathrm{S}$ & $\mathrm{Vm} / \mathrm{s}$ & $\mathrm{P} \%$ & $\mathrm{H}_{\mathrm{st}} \mathrm{m}$ & $\mathrm{K}_{\mathrm{t}}$ & $\mathrm{U} \mathrm{m} / \mathrm{s}$ \\
\hline 1 & 48.84 & 1.52 & 5.53 & 12 & 4.74 & 0.38 & 0.27 & 0.21 \\
\hline 2 & 49.18 & 1.96 & 8.00 & 20 & 0.53 & 0.55 & 0.31 & 0.26 \\
\hline 3 & 68.69 & 1.35 & 5.31 & 12 & 5.86 & 0.34 & 0.27 & 0.20 \\
\hline 4 & 63.94 & 1.89 & 7.71 & 18 & 0.81 & 0.51 & 0.29 & 0.28 \\
\hline 5 & 94.72 & 0.79 & 4.47 & 12 & 4.80 & 0.29 & 0.32 & 0.16 \\
\hline 6 & 87.60 & 1.39 & 7.36 & 18 & 0.47 & 0.43 & 0.32 & 0.25 \\
\hline 7 & 101.60 & 0.29 & 2.97 & 5 & 40.00 & 0.16 & 0.57 & 0.10 \\
\hline
\end{tabular}

Figure 9. Bathymetry based on the survey of April 2007. 

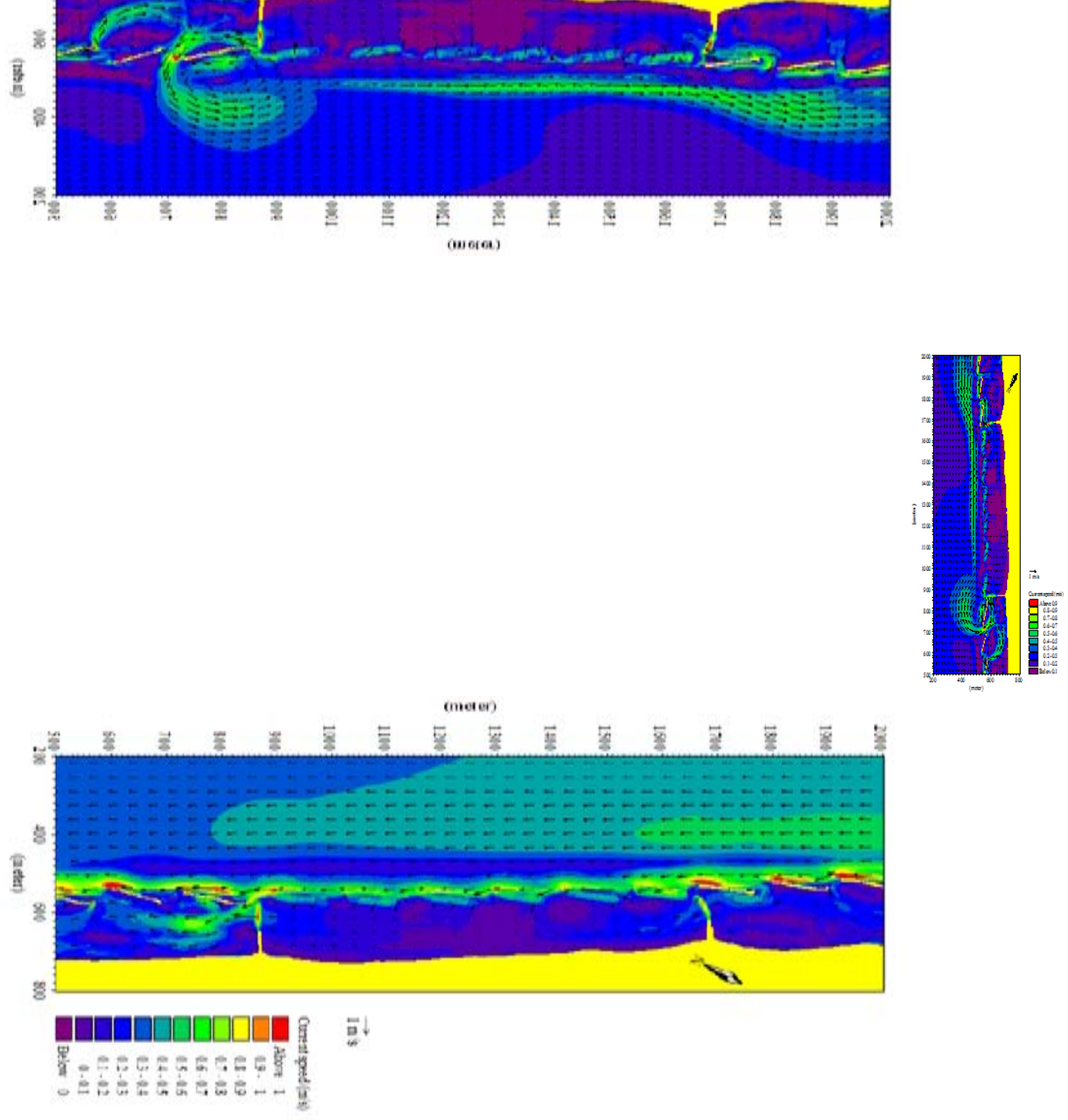

Figure 10. Current velocities and intensities in colour scale and directions obtained from Mike $21 \mathrm{HD}$ for a typical storm from Bora (top) and from Scirocco (bottom).

\section{CONCLUSIONS}

Monitoring activities occurred in between 2003 and 2009 focused on Igea Marina costal area show that the experimental work has achieved its forecasted objectives (Figure 11.):

- $\quad$ water and sea bed quality improvement;

- beach widening;

- $\quad$ tourist number increasing.

Operating costs are higher than the previous asset's operating costs, due to the bigger nourishment action.

Negative aspects are only related to a $200 \mathrm{~m}$ beach erosion in the very southern part of the observed area and to the partial collapse of groynes, occurred in December 2003 just after their construction.

The experimental works could be realized in other areas of the Emilia-Romagna's coastline protected by detached breakwaters.

In order to reach environmental improvement and landscape's enhancement the community will have to afford bigger operating costs. 

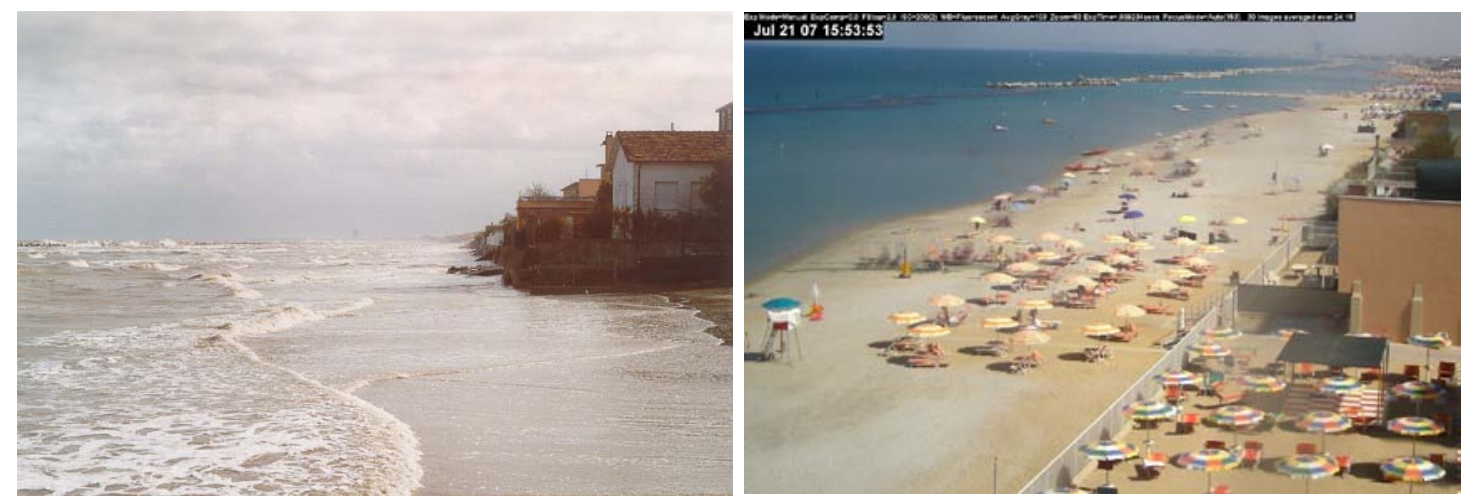

Figure 11. Igea Marina beach in 2001, before the experimental work and in 2007 after the nourishment

\section{REFERENCES}

Archetti R. and Zanuttigh B. Integrated monitoring of the hydro-morphodynamics of a beach protected by low crested detached breakwaters. 2010. Coastal Eng. 57.. Pp. 879-891

Archetti R. Torricelli E., Erdman R, and Lamberti A. 2009. First application of a new imaging system for the coastal monitoring. Proceedings of the V International Conference on Coastal Structures.

Idroser S.p.A. 1996. Progetto di piano per la difesa dal mare e la riqualificazione ambientale del litorale della Regione Emilia-Romagna. Relazione Generale. Bologna. In Italian.

Martinelli, L., Zanuttigh, B., Lamberti, A. \& Gaeta G. Analysis of an unexpected groin failure at a low crested scheme, Proc. XXX Int. Conf. Coastal Eng., World Scientific, 2007, vol. 4, 4116-4128.

Nicholls R. J., de la Vega-Leinert A C., 2008. Implications of sea-level rise for Europe's coasts. Journal of Coastal Research, 24 (2), 285-442.

Nicholls, R.J., and R.J.T. Klein, 2005: Climate change and coastal management on Europe's coast.Managing European Coasts: Past, Present and Future, Springer, Environmental Science Monograph Series. 199-226.

Preti, M., A. Lamberti, L. Martinelli, C. Albertazzi, S. Sammarini, 2005. An effort toward renaturalisation of Igea Marina beach: transformation of six barriers into one LCS, Proc. 7th MEDCOAST, 919-930.

Preti M., De Nigris, N., Morelli, M., Monti, M., Bonsignore, F., Aguzzi, M., 2009. Stato del litorale emiliano-romagnolo all'anno 2007 e piano decennale di gestione, I quaderni dell'ARPA. Bologna. In Italian. 